EMITTER International Journal of Engineering Technology

ISSN: 2443-1168, Vol. 8, No. 1, June 2020, pp. 126 139

DOI : 10.24003 /emitter.v7i2.423

\title{
Comparation of SAW Method and Topsis in Assesing The Best Area Using HSE Standards
}

\author{
Bendra Wardana*, Roni Habibi², M. Harry K Saputra ${ }^{3}$ \\ 1,2,3 Applied Bachelor Program of Informatics Engineering, Politeknik Pos Indonesia, \\ Jl. Sariasih No. 54, Sarijadi, Sukasari, Bandung 40151, Indonesia \\ Telp. +6222-2009562 Fax. +6222-2011099, \\ Correspondence: E-mail: bendwardana@gmail.com",ronihabibi@poltekpos.ac.id², \\ harrysaputra@poltekpos.ac.id ${ }^{3}$
}

Received November 27, 2019; Revised December 26, 2019; Accepted January 26, 2020

\begin{abstract}
PT. Pertamina Gas is a company engaged in the midstream and downstream industry sectors of Indonesian gas. Currently, the process to access the best areas in PT. Pertamina Gas has not been computerizedand it is still doing manually. In assessing the area itself, this method is considered less effective and efficient to determine the best area. Area Assessment according to PT. Pertamina Gas itself is important to iincrease the performance and safety in improving PT. Pertamina Gas Health, Safety, Environment quality. Therefore, we need a system to determine which areas are the best in the PT. Pertamina Gas environment, using predetermined criteria. To create a system commenting on the area in PT. Pertamina Gas Environment, the author used the method Simple Additive Weighting (SAW) and Techniques for Other References With Similarities to Ideal Solutions (TOPSIS) for the best process of conversation and area testing.This study suggests finding the best method for reporting and helping to make decisions based on the best alternative value. The results obtained from this study show that the testing using SAW method is more optimal than using TOPSIS method, with the value of sensitivity change for SAW is 2.4 and TOPSIS is 0.7754 .
\end{abstract}

Keywords: PT. Pertamina Gas, SAW, Topsis, Sensitivity Test, Best Area.

\section{INTRODUCTION}

Health, Safety and Environmental Protection (K3LL) or also known as Health, Safety and Environment (HSE) become an important part that never escapes the attention of the Company [1]. The Company's line of business is very easy to dispute by removing what is rejected by its employees considering the nature of the gas released is highly flammable. Pertamina is very concerned about safety aspects for workers, therefore it is a given 
necessity the company has developed into a strong commitment to make Pertamina Gas always make efforts to improve HSE.

The implementation of HSE is not only carried out by companies, but also all workers, without exception. HSE applies to all matters relating to all activities and the impact of these activities on employees, the environment and the communities in which the company operates [2]. Good coordination between employees and field officers is believed to be able to make all parties aware of the dangers that are always threatening in every operational process. As an effort to increase HSE, one of the efforts carried out by Pertamina gas is to carry out a process of assessing the best areas each year of the areas that are within the scope of the company. The problem with Pertamina gas at this case is conducting an assessment process that has not been computerized with an appropriate system. In the application, there are many obstacles that occur in the assessment of the area, such as errors in inputting values, and in ranking the area still using a simple formula in Excel and there is no system to assist the assessment, they do the assessment manually, without any system or method used in helping in the assessment of decision making. This process will require quite a long time to do the decision system [3].

To facilitate calculations in determining the best area assessment, it is necessary to have a computerized system [4] in assisting the appraisers to assess areas based on existing criteria, and assess which areas are the best [5]. Therefore, the authors try to solve the problem by applying a computerbased decision-making method in processing data areas and criteria to get the decision in accordance with what is expected. In information technology, decision support systems determine one branch of science including information systems and intelligent systems [6]. The SAW method is used because it has a basic concept of weighting and performance rating for each alternative on each attribute [7]. The selection of the SAW method is based because it can determine the value of each weight for various attributes, then proceed with the ranking process which will choose alternatives the best of the number of alternatives, in this case the intended alternative is feasible or not to be awarded as the best area based predicate some criteria predetermined criteria [8]. With the ranking process, it is expected that the assessment will be more precise because it is based on the value of existing criteria and the weighted value predetermined so that you will get more precise results on the area which will be the best in PT.Pertamina Gas [9]. Method Technique for Order Performance of Similarity to Ideal Solution (Topsis) has the provision that the alternative chosen must have the farthest distance from solving positive and negative ideals from the different points of view we see by using a relative closeness of an alternative that is in the case study [10]. By using a TOPSIS method based on a decision-making system that classifies web services according to non-functional needs [11]. The TOPSIS decision method of the linguistic lattice implications of algebra based on the weighted normalization method is proposed to determine the 
decision-making process [12]. Therefore, the writer will try to apply the Comparison of SAW and Topsis Methods in the Best Area Assessment Using HSE Standards at PT. Pertamina Gas.

\section{RELATED WORKS}

In the previous study, SAW and TOPSIS methods are used to implement GIS and multi-criteria decision analysis (MCDA) technique as a multi-criteria method enhance decision making to evaluate areas suitable for planning priority plan for planting corn, and soybean plants [13]. and this method is also used in making decision support systems for help managers choose database management software (DBM) which right for their company, using Simple Additive Weighting (SAW) and (TOPSIS) [14].

\section{ORIGINALITY}

In this study, it was agreed to create a regional assessment system in PT. Pertamina Gas. Area Assessment according to PT. Pertamina Gas itself fulfills its importance for Improve performance and increase security, Safety, Environment PT.Pertamina Gas. Therefore we need a system, which can determine which areas are the best in the PT. Pertamina Gas environment, using predetermined criteria. This study uses the method of Simple Additive Weighting (SAW) and Techniques For Others. This research is to find the best method in this case and help make decisions about the best alternative value.

\section{SYSTEM DESIGN}

In this study, the waterfal method is needed so that the research can proceed as expected. The research method is an experimental method that uses the decision support system method in its activities. The flow of research methodology can be seen in Figure 1, which is as follows:

Based on the research Methodology Flow Diagram at Figure 1, the research method is not far from the formulation of the problem, literature study, data collection techniques, analysis of the current system and the system to be built, after which design and coding are done which includes the application of the saw and topsis methods therein. After testing the system and drawing conclusions generated from these trials. 


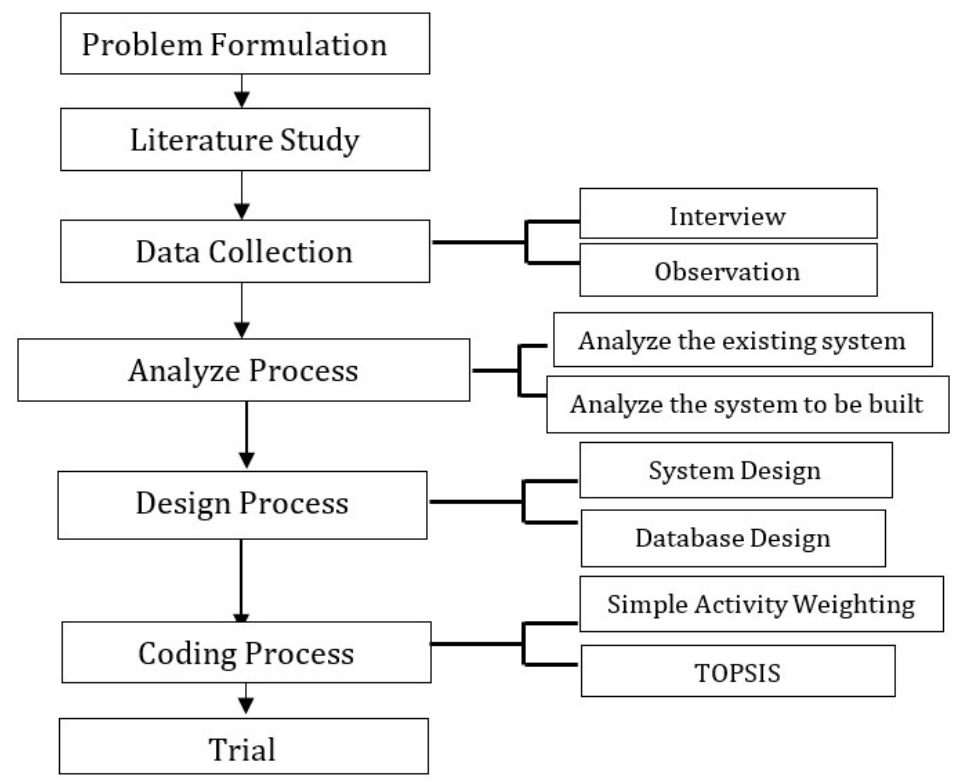

Figure 1. Research Methodology

\subsection{Data Set}

At this stage steps are needed to gather data needed to achieve research objectives. Successful data collection to start even in data processing. Data collection is done is registration on-going activities. Apart from that also seen several lots documents that must be recorded in the book during the observations made.

\subsubsection{Primary Data}

Interview: Interview conducted with one of the people HSE part Kuswana who discussed about how to move in the area assessment best, and what problems are common.

Observation: Observation technique is a technique of collecting data by means of researchers make observations directly in the field. Observation method is a method of data collection that is done by observing and record systematically the symptoms investigated. Observation done according to certain procedures and rules so that it can be repeated again by researchers and observations provide the possibility to be interpreted in a manner scientific.

\subsubsection{Secondary Data}

Secondary data is data taken directly from the company. In this research the company provides alternative data to be assessed, and criteria data as a support in decision making. 
Table 1. PT. Pertamina Gas Area

\begin{tabular}{|c|c|c|}
\hline Code & Area Name & Address \\
\hline A01 & North Sumatera Area & $\begin{array}{l}\text { Jl. Dr. Wahidin No. } 1 \text { Pangkalan Brandan } \\
\text { North Sumatera - } 20857\end{array}$ \\
\hline A02 & Central Sumatera Area & $\begin{array}{l}\text { Jl. AKBP Cek Agus No 10, Kenten, Palembang } \\
30114\end{array}$ \\
\hline A03 & Southern Sumatera Area & $\begin{array}{l}\text { Jl. AKBP Cek Agus No 10, Kenten, Palembang } \\
30114\end{array}$ \\
\hline A04 & West Java Area & $\begin{array}{l}\text { Komplek Perumahan Dinas Distrik TGD } \\
\text { Jl. Raya Industri Tegalgede South Cikarang, } \\
\text { Bekasi - } 17550\end{array}$ \\
\hline A05 & Eastern Java Area & Jl. Darmo Kali No. 40-42 Surabaya 60241 \\
\hline A06 & Kalimantan Area & $\begin{array}{l}\text { KNE Building, Jl. Pupuk Raya No.55, Bontang } \\
\text { Barat, Bontang, East Kalimantan Timur } \\
75313\end{array}$ \\
\hline
\end{tabular}

Table 2. Assessment Criteria

\begin{tabular}{|l|l|l|}
\hline Code & Criteria Name & Weight \\
\hline C01 & HSE Meeting & $30 \%$ \\
\hline C02 & Fire Drill & $20 \%$ \\
\hline C03 & Simulasi Tanggap Darurat & $20 \%$ \\
\hline C04 & Management Walk Throught & $15 \%$ \\
\hline C05 & Training Aspek QC dan HSE & $15 \%$ \\
\hline
\end{tabular}

\subsection{SAW Method}

The Simple Additive Weighting (SAW) method is often also known as the weighted sum method. one of the basic concepts used in the SAW method is to find the number of rankings for each alternative to all the attributes contained in the data used. The SAW method requires a decision matrix normalization step (X) for a scale that can be compared with all alternative rankings available therein. The SAW method is very well known and is very widely used in facing the challenges of MADM. The steps in completing the SAW Method are:

$$
n_{i j}\left\{\begin{array}{c}
\frac{x_{i j}}{\operatorname{Max} x_{i j}} \\
\frac{i}{\operatorname{Min} x_{i j}} \\
\frac{i}{x_{i j}}
\end{array}\right.
$$

1. Provide criteria that will be used as a goal in decision-making. Determines the suitability rating of each alternative on each criterion.

2. The next step is to describe the matrix in accordance with existing criteria, then normalize the matrix based on the equation specified by the attribute type so that the obtained matrix image is sought.

3. After that obtained from the ranking process, which is the sum of the multiplications of the normalized vector $\mathrm{R}$ matrix, the weight so the 
highest value is chosen as the highest or best alternative (Ai) as the solution obtained to take a decision.

\subsection{TOPSIS Method}

TOPSIS method is a method of decision making with a model of the number of distances between alternatives and ideal solutions. The TOPSIS method was chosen because it is able to choose the best from alternative choices. In this case the alternative is adjusted to the researcher's research, then calculated based on the criteria determined by steps the The TOPSIS method is very simple, very easy to understand, very effective and efficient in its use [15]. Troubleshooting steps with TOPSIS [16] :

1. The first step is to make a normalized decision matrix for usage needs.

$$
r i j=\frac{x_{i j}}{\sqrt{\sum_{i=1}^{m} x_{i j}^{2}}}
$$

2. Form a normalized weighted decision matrix.

$$
y i j=w_{i j} r_{i j}
$$

3. Making a matrix of solutions to the ideal ideal problem \& the matrix of the ideal ideal solution.

$$
\begin{aligned}
& y_{j}^{+}=\operatorname{Max} y_{i j} \\
& y_{j}^{-}=\operatorname{Min} y_{i j}
\end{aligned}
$$

4. Make the distance between the values of each alternative with a positive ideal matrix \& a negative ideal solution matrix.

$$
\begin{aligned}
& D_{i}^{+}=\sqrt{\sum_{j=1}^{n}\left(y_{i}^{+}-y_{i j}\right)^{2}} \\
& \left.D_{i}^{-}=\sqrt{\sum_{j=1}^{n}\left(y_{i}^{-}\right.}-y_{i j}\right)^{2}
\end{aligned}
$$

5. Make the preference value for each alternative.

$$
R C=\frac{D_{i}^{-}}{D_{i}^{-}+D_{i}^{+}}
$$

\subsection{Sensitivity Test SAW Method and TOPSIS Method}


Sensitivity testing is a process of knowing and getting results from a comparison of the two methods. This is done in research to find out how sensitive the method is if applied in a case study, increasingly sensitive value obtained from each ranking change in each method, then the method will be chosen. The degree of sensitivity of each attribute is obtained through the steps as follows [17]:

1. Determine all attribute weights, wj $=1$ (initial weight), with $\mathrm{j}=1,2, \ldots .$. number attribute.

2. Change the weight of one criterion while the weight of the other criteria is fixed.

3. Normalize the weight value.

4. Apply the two methods (SAW and Topsis) to weights the attributes formed in step 3.

5. Calculate percentage change in rank by comparing how many a lot of ranking changes that occur when compared with the current conditions the same weight.

\section{EXPERIMENT AND ANALYSIS \\ 5.1 Experiment}

Area assessment is considered very important for increasing the area and pertamina gas itself. Area assessment is also important as a management tool for assessing area efficiency. In order to improve the performance of areas (including human resource development) the company must pay great attention to the areas covered by employees in it. Therefore the PT. Pertamina gas area is the main target in this assessment.

\subsubsection{Saw Method}

Based on the steps to determine the best area of PT.Pertamina Gas by using the SAW Method, then what must be done give the value of each Alternative that is in each assessment that has been determined to produce a value that suits your needs.

Table 3. Match Table Ratings of Each Criteria

\begin{tabular}{|l|l|l|l|l|l|}
\hline \multirow{2}{*}{ Alternative } & \multicolumn{5}{|c|}{ Provision Criteria } \\
\cline { 2 - 7 } & C1 & C2 & C3 & C4 & C5 \\
\hline North Sumatera Area & 3 & 4 & 4 & 5 & 1 \\
\hline Central Sumatera Area & 5 & 3 & 4 & 1 & 5 \\
\hline Southern Sumatera Area & 4 & 5 & 5 & 5 & 1 \\
\hline West Java Area & 4 & 5 & 4 & 1 & 5 \\
\hline Eastern Java Area & 3 & 4 & 5 & 5 & 1 \\
\hline Kalimantan Area & 4 & 5 & 3 & 1 & 1 \\
\hline
\end{tabular}

Then from the above calculation, the normalization matrix value is obtained. Value These will be made into the matrix. The following are the results of the calculation Normalization matrix 
Table 4. Normalization Matrix

\begin{tabular}{|l|c|c|c|c|c|}
\hline \multirow{2}{*}{ Alternative } & \multicolumn{5}{|c|}{ Provision Criteria } \\
\cline { 2 - 6 } & PC1 & PC2 & PC3 & PC4 & PC5 \\
\hline North Sumatera Area & 0.6 & 0.8 & 0.8 & 1.0 & 0.2 \\
\hline Central Sumatera Area & 1.0 & 0.6 & 0.8 & 0.2 & 1.0 \\
\hline Southern Sumatera Area & 0.8 & 1.0 & 1.0 & 1.0 & 0.2 \\
\hline West Java Area & 0.8 & 1.0 & 0.8 & 0.2 & 1.0 \\
\hline Eastern Java Area & 0.6 & 0.8 & 1.0 & 1.0 & 0.2 \\
\hline Kalimantan Area & 0.8 & 1.0 & 0.6 & 0.2 & 0.2 \\
\hline
\end{tabular}

Based on the ranking results, the highest value is the Southern Sumatra Area, and the lowest value is Kalimantan Area.

Table 5. Ranking Results

\begin{tabular}{|l|c|c|}
\hline Alternative & Value & Rangking \\
\hline North Sumatera Area & 0.68 & 5 \\
\hline Central Sumatera Area & 0.76 & 3 \\
\hline Southern Sumatera Area & 0.82 & 1 \\
\hline West Java Area & 0.78 & 2 \\
\hline Eastern Java Area & 0.72 & 4 \\
\hline Kalimantan Area & 0.62 & 6 \\
\hline
\end{tabular}

\subsubsection{TOPSIS Method}

Based on the steps to determine the best area of PT.Pertamina Gas by using the TOPSIS Method, then what must be done gives the value of each Alternative on each predetermined criterion.

Table 6. Value Comparation

\begin{tabular}{|l|c|c|c|c|c|}
\hline \multirow{2}{*}{ Alternative } & \multicolumn{5}{|c|}{ Provision Criteria } \\
\cline { 2 - 7 } & PC1 & PC2 & PC3 & PC4 & PC5 \\
\hline North Sumatera Area & 3 & 4 & 4 & 5 & 1 \\
\hline Central Sumatera Area & 5 & 3 & 4 & 1 & 5 \\
\hline Southern Sumatera Area & 4 & 5 & 5 & 5 & 1 \\
\hline West Java Area & 4 & 5 & 4 & 1 & 5 \\
\hline Eastern Java Area & 3 & 4 & 5 & 5 & 1 \\
\hline Kalimantan Area & 4 & 5 & 3 & 1 & 1 \\
\hline
\end{tabular}

Table 7. Value Divider

\begin{tabular}{|l|l|l|l|l|l|}
\hline Divider & 9.5394 & 10.7703 & 10.3441 & 8.8318 & 7.3845 \\
\hline
\end{tabular}

Table 8. Nomalizaton Matrix

\begin{tabular}{|l|c|c|c|c|c|}
\hline \multirow{2}{*}{ Alternative } & \multicolumn{5}{|c|}{ Provision Criteria } \\
\cline { 2 - 6 } & PC1 & PC2 & PC3 & PC4 & PC5 \\
\hline North Sumatera Area & 0.3145 & 0.3714 & 0.3867 & 0.5661 & 0.1361 \\
\hline Central Sumatera Area & 0.5241 & 0.2785 & 0.3867 & 0.1132 & 0.6804 \\
\hline Southern Sumatera Area & 0.4193 & 0.4642 & 0.4834 & 0.5661 & 0.1361 \\
\hline
\end{tabular}




\begin{tabular}{|l|l|l|l|l|l|}
\hline West Java Area & 0.4193 & 0.4642 & 0.3867 & 0.1132 & 0.6804 \\
\hline Eastern Java Area & 0.3145 & 0.3714 & 0.4834 & 0.5661 & 0.1361 \\
\hline Kalimantan Area & 0.4193 & 0.4642 & 0.2900 & 0.1132 & 0.1361 \\
\hline
\end{tabular}

Table 9. Chip weight

\begin{tabular}{|l|c|c|c|c|c|}
\hline Criteria & PC1 & PC2 & PC3 & PC4 & PC5 \\
\hline Weightt & 0.3 & 0.2 & 0.2 & 0.15 & 0.15 \\
\hline Cost/Benetfit & Benetfit & Benetfit & Benetfit & Benetfit & Benetfit \\
\hline
\end{tabular}

Table 10. Weighted Normalized Matrix

\begin{tabular}{|l|l|l|l|l|l|}
\hline \multirow{2}{*}{ Alternative } & \multicolumn{5}{|c|}{ Provision Criteria } \\
\cline { 2 - 6 } & PC1 & PC2 & PC3 & PC4 & PC5 \\
\hline North Sumatera Area & 0.0943 & 0.0743 & 0.0773 & 0.0849 & 0.0204 \\
\hline Central Sumatera Area & 0.1572 & 0.0557 & 0.0773 & 0.0170 & 0.1021 \\
\hline Southern Sumatera Area & 0.1258 & 0.0928 & 0.0967 & 0.0849 & 0.0204 \\
\hline West Java Area & 0.1258 & 0.0928 & 0.0773 & 0.0170 & 0.1021 \\
\hline Eastern Java Area & 0.0943 & 0.0743 & 0.0967 & 0.0849 & 0.0204 \\
\hline Kalimantan Area & 0.1258 & 0.0928 & 0.0580 & 0.0170 & 0.0204 \\
\hline
\end{tabular}

Table 11. Value of Positive and Negative Ideal Solutions

\begin{tabular}{|l|c|c|c|c|c|}
\hline Provision Criteria & PC1 & PC2 & PC3 & PC4 & PC5 \\
\hline Yij+ & 0.1572 & 0.0928 & 0.0967 & 0.0849 & 0.1021 \\
\hline Yij- & 0.0943 & 0.0557 & 0.0580 & 0.0170 & 0.0204 \\
\hline
\end{tabular}

Table 12. Distance Positive and Negative Ideal Solution

\begin{tabular}{|l|l|l|}
\hline Alternative/Criteria & S+ & S- \\
\hline North Sumatera Area & 0.1065 & 0.0730 \\
\hline Central Sumatera Area & 0.0798 & 0.1049 \\
\hline Southern Sumatera Area & 0.0875 & 0.0921 \\
\hline West Java Area & 0.0773 & 0.0970 \\
\hline Eastern Java Area & 0.1047 & 0.0803 \\
\hline Kalimantan Area & 0.1173 & 0.0487 \\
\hline
\end{tabular}

Table 13. Relative Proximity Calculation

\begin{tabular}{|l|l|l|l|c|}
\hline Alternative/Criteria & S+ & S- & RC & Rangking \\
\hline North Sumatera Area & 0.1065 & 0.0730 & 0.4068 & 5 \\
\hline Central Sumatera Area & 0.0798 & 0.1049 & 0.5679 & 1 \\
\hline Southern Sumatera Area & 0.0875 & 0.0921 & 0.5128 & 3 \\
\hline West Java Area & 0.0773 & 0.0970 & 0.5564 & 2 \\
\hline Eastern Java Area & 0.1047 & 0.0803 & 0.4341 & 4 \\
\hline Kalimantan Area & 0.1173 & 0.0487 & 0.2932 & 6 \\
\hline
\end{tabular}

\subsubsection{Comparison of SAW and TOPSIS methods}

Based on the ranking results with the SAW Method, the highest value is Southern Sumatra Area, and the lowest value is Kalimantan Area. 
Table 14. Rangking Result SAW Method

\begin{tabular}{|l|c|c|}
\hline Alternative & Value & Rangking \\
\hline North Sumatera Area & 0.68 & 5 \\
\hline Central Sumatera Area & 0.76 & 3 \\
\hline Southern Sumatera Area & 0.82 & 1 \\
\hline West Java Area & 0.78 & 2 \\
\hline Eastern Java Area & 0.72 & 4 \\
\hline Kalimantan Area & 0.62 & 6 \\
\hline
\end{tabular}

Whereas in Ranking Results with Topsis Method, the highest value is Central Sumatra Area, and the lowest value is Kalimantan area.

Table 15. Rangking Result Topsis Method

\begin{tabular}{|l|l|c|}
\hline Alternative/Criteria & RC & Rangking \\
\hline North Sumatera Area & 0.4068 & 5 \\
\hline Central Sumatera Area & 0.5679 & 1 \\
\hline Southern Sumatera Area & 0.5128 & 3 \\
\hline West Java Area & 0.5564 & 2 \\
\hline Eastern Java Area & 0.4341 & 4 \\
\hline Kalimantan Area & 0.2932 & 6 \\
\hline
\end{tabular}

\subsubsection{Sensitivity Test}

Using the determined value $\mathrm{W}$ (weight) $=(0.3,0.2,0.2 .0 .15$, 0.15), the resulting comparison of the SAW method and TOPSIS at table 16.

Table 16. Comparison of SAW and TOPSIS methods

\begin{tabular}{|l|l|l|}
\hline Alternative/Criteria & SAW & TOPSIS \\
\hline North Sumatera Area & 0.68 & 0.4068 \\
\hline Central Sumatera Area & 0.76 & 0.5679 \\
\hline Southern Sumatera Area & 0.82 & 0.5128 \\
\hline West Java Area & 0.78 & 0.5564 \\
\hline Eastern Java Area & 0.72 & 0.4341 \\
\hline Kalimantan Area & 0.62 & 0.2932 \\
\hline MAX & 0.82 & 0.5679 \\
\hline
\end{tabular}

Tested by raising the criteria weight by 0.5 . Weight $(\mathrm{w})=(0.8,0.2,0.2$, $0.15,0.15$ ) the value of $w$ in criterion 1 is increased by 0.5 .

From the sensitivity test results on the first criteria, it produces the following comparison data at table 17. 
Table 17. Sensitivity Criteria 1

\begin{tabular}{|l|l|l|}
\hline Alternative/Criteria & SAW & TOPSIS \\
\hline North Sumatera Area & 0.98 & 0.2793 \\
\hline Central Sumatera Area & 1.26 & 0.7015 \\
\hline Southern Sumatera Area & 1.22 & 0.5073 \\
\hline West Java Area & 1.18 & 0.5313 \\
\hline Eastern Java Area & 1.02 & 0.3 \\
\hline Kalimantan Area & 1.02 & 0.3945 \\
\hline MAX & 1.26 & 0.7015 \\
\hline Change & 0.44 & 0.1336 \\
\hline
\end{tabular}

Using the determined weight $(\mathrm{w})=(0.5,0.7,0.2,0.15,0.15)$ the value of $w$ in criterion 2 is increased to 0.5 . From the sensitivity test results on the second criterion, it produces a comparison at table 18.

Table 18. Sensitivity Criteria 2

\begin{tabular}{|l|l|c|}
\hline Alternative/Criteria & SAW & TOPSIS \\
\hline North Sumatera Area & 1.08 & 0.4376 \\
\hline Central Sumatera Area & 1.06 & 0.4148 \\
\hline Southern Sumatera Area & 1.32 & 0.6390 \\
\hline West Java Area & 1.28 & 0.6713 \\
\hline Eastern Java Area & 1.12 & 0.4548 \\
\hline Kalimantan Area & 1.12 & 0.5327 \\
\hline MAX & 1.32 & 0.6713 \\
\hline Change & 0.5 & 0.1034 \\
\hline
\end{tabular}

Using weight $(w)=(0.3,0.2,0.7,0.15,0.15)$ the value of $w$ in criterion 3 is increased to 0.5 . From the sensitivity test results on the third criterion, it produces a comparison at table 19.

Table 19. Sensitivity Criteria 3

\begin{tabular}{|l|l|c|}
\hline Alternative/Criteria & SAW & TOPSIS \\
\hline North Sumatera Area & 1.08 & 0.4393 \\
\hline Central Sumatera Area & 1.16 & 0.5453 \\
\hline Southern Sumatera Area & 1.32 & 0.6451 \\
\hline West Java Area & 1.18 & 0.5362 \\
\hline Eastern Java Area & 1.22 & 0.5930 \\
\hline Kalimantan Area & 0.92 & 0.2177 \\
\hline MAX & 1.32 & 0.6451 \\
\hline Change & 0.5 & 0.0722 \\
\hline
\end{tabular}

Using weight $(w)=(0.3,0.2,0.2,0.65,0.15)$ the value of $w$ in criterion 4 is increased to 0.5 . From the sensitivity test results on the fourth criterion, it produces a comparison at table 20. 
Table 20. Sensitivity Criteria 4

\begin{tabular}{|l|l|l|}
\hline Alternative/Criteria & SAW & TOPSIS \\
\hline North Sumatera Area & 1.18 & 0.7352 \\
\hline Central Sumatera Area & 0.86 & 0.2607 \\
\hline Southern Sumatera Area & 1.32 & 0.7747 \\
\hline West Java Area & 0.88 & 0.2464 \\
\hline Eastern Java Area & 1.22 & 0.7396 \\
\hline Kalimantan Area & 0.72 & 0.1359 \\
\hline MAX & 1.32 & 0.7747 \\
\hline Change & 0.5 & 0.2068 \\
\hline
\end{tabular}

Using weight $(\mathrm{w})=(0.3,0.2,0.2,0.15,0.65)$ the value of $\mathrm{w}$ in criterion 5 is increased to 0.5 . From the sensitivity test results on the fifth criterion, it results in the data a comparison at table 21.

Table 21. Sensitivity Criteria 5

\begin{tabular}{|l|l|l|}
\hline Alternative/Criteria & SAW & TOPSIS \\
\hline North Sumatera Area & 0.78 & 0.1685 \\
\hline Central Sumatera Area & 1.26 & 0.8185 \\
\hline Southern Sumatera Area & 0.92 & 0.2059 \\
\hline West Java Area & 1.28 & 0.8223 \\
\hline Eastern Java Area & 0.82 & 0.1825 \\
\hline Kalimantan Area & 0.72 & 0.1180 \\
\hline MAX & 1.28 & 0.8223 \\
\hline Change & 0.46 & 0.2544 \\
\hline
\end{tabular}

\subsection{Result}

The percentage of change in rank using the SAW and TOPSIS methodsmin the best area is as shown at Table 22 .

Table 22. Percentage of Sensitivity

\begin{tabular}{|l|l|c|}
\hline Alternative/Criteria & SAW & TOPSIS \\
\hline K1 +0.5 & 0.1336 & 0.44 \\
\hline $\mathrm{K} 2+0.5$ & 0.1034 & 0.5 \\
\hline $\mathrm{K} 3+0.5$ & 0.0772 & 0.5 \\
\hline $\mathrm{K} 4+0.5$ & 0.2068 & 0.5 \\
\hline $\mathrm{K} 5+0.5$ & 0.2544 & 0.46 \\
\hline Count & 0.7754 & 2.4 \\
\hline
\end{tabular}

Based on the results of the summation above, it can be concluded that the method of SAW has a sensitivity value of 2.4 meanwhile Topsis is 0.7754. Thus, for this case an alternative solution or the recommended method is to use the SAW Method.

\section{CONCLUSION}

After doing the research, we can conclude that using the provided process, the best area in PT. Pertamina Gas can be assisted and provided in 
Health, Safety and Environment case in the assessment of existing areas for distribution of PT. Pertamina Gas. Based on several criteria and applying the SAW and Topsis methods, the process of announcing areas in PT. Pertamina Gas could be made easily. According to the results of the sensivity test, it can be concluded that the method of SAW has a sensitivity value of 2.4 meanwhile Topsis is 0.7754 .

\section{Acknowledgements}

This research was supported by the Healt Safety and Environment (HSE) Division of PT. Pertamina Gas Head Office.

\section{REFERENCES}

[1] J. Kang, J. Zhang, and J. Gao, "Improving performance evaluation of health, safety and environment management system by combining fuzzy cognitive maps and relative degree analysis" Safety science, vol. 87, pp. 92-100, 2016.

[2] P. S. Gholami, P. Nassiri, R. Yarahmadi, A. Hamidi, and R. Mirkazemi, "Assessment of health safety and environment management system function in contracting companies of one of the petro-chemistry industries in iran, a case study", Safety Science, vol. 77, pp. 42. 47, 2015.

[3] S. S. Harahap et al., "Sistem pendukung keputusan penyetujuan kartu kredit pada pt. bank rakyat indonesia dengan menggunakan metode simple additive weighting (saw)," Jurnal Sistem Informasi dan Ilmu Komputer Prima (JUSIKOM PRIMA), vol. 2, no. 2, pp. 1-7, 2019.

[4] N. Nurjannah, Z.Arifin, and D. M. Khairina, "Sistem pendukung keputusan pembelian sepeda motor dengan metode weighted product," J. Inform. Mulawarman, vol. 10, no. 2, pp. 2-6, 2015.

[5] D. M. Khairina, D. Ivando, and S. Maharani, "Implementasi metode weighted product untuk aplikasi pemilihan smartphone android," Jurnal Infotel, vol. 8, no. 1, pp. 16-23, 2016.

[6] A. Wedhasmara et al., "Sistem pendukung keputusan pemilihan pembelian kendaraan bermotor dengan metode saw," Jurnal Sistem Informasi, vol. 2, no. 2, 2014.

[7] M. Muthohir and A. Zainudin, "Penerapan metode simple additive weight (saw) pada sistem informasi pemilihan jurusan berbasis decision support system," Smart Comp: Jurnalnya Orang Pintar Komputer, vol. 7, no. 1, pp. 230-260, 2018.

[8] S. S. Sundari and Y. F. Taufik, "Sistem pendukung keputusan penerimaan pegawai baru dengan menggunakan metode simple additive weighting (saw)," Sisfotenika, vol. 4, no. 2, 2014.

[9] Y. Djamain, "Sistem pendukung keputusan penerimaan pegawai baru pt. pln (persero) kantor pusat dengan menggunakan metode simple additive weighting (saw)," Jurnal Teknik Informatika, vol. 8, no. 1, 2015. 
[10] A. P. Windarto, "Implementasi metode topsis dan saw dalam memberikan reward pelanggan," Kumpul. J. Ilmu Komput, vol. 4, no. 1, pp. 88-101, 2017.

[11] C. H. Primasari and D. B. Setyohadi, "Financial analysis and topsis implementation for selecting the most profitable investment proposal in goat farming," in 2017 2nd International conferences on Information Technology, Information Systems and Electrical Engineering (ICITISEE). IEEE, 2017, pp. 51-56.

[12] H. Wang, J. Meng, L. Zou, S. Luo, and Y. Shi, "Linguistic-valued lattice implication algebra topsis method based on entropy weight method," in 2017 12th International Conference on Intelligent Systems and Knowledge Engineering (ISKE) IEEE, 2017, pp. 1-8.

[13] R. Anggrainingsih, A. Wiyanto, and A. Aziz, "Saw-topsis implementation to determine an appropriate dbms software," Journal of Telecommunication, Electronic and Computer Engineering (JTEC), vol. 10, no. 2-4, pp. 101-105, 2018.

[14] J. Seyedmohammadi, F. Sarmadian, A. A. Jafarzadeh, M. A. Ghorbani, and F. Shahbazi, "Application of saw, topsis and fuzzy topsis models in cultivation priority planning for maize, rapeseed and soybean crops," Geoderma, vol. 310, pp. 178-190, 2018.

[15] C. Huibao and L. Lei, "The study on appraisal of enterprise employee performance," in 2009 First International Workshop on Database Technology and Applications. IEEE, 2009, pp. 632-637.

[16] P. Prabaharan and I. Perera, "Tool support for efective employee performance appraisal in software engineering industry," in 2017 Moratuwa Engineering Research Conference (MERCon). IEEE, 2017, pp. 473-478.

[17] G. A. Mendoza and H. Martins, "Multi-criteria decision analysis in natural resource management: A critical review of methods and new modelling paradigms," Forest ecology and management, vol. 230, no. 13, pp. 1-22, 2006. 